\title{
REMINDER PENGONTROLAN PERAWATAN GIGI BERBASIS ANDROID
}

\author{
A.Astuty Indriani ${ }^{1}$, Ratnawati $^{2}$, First Wanita $^{3}$ \\ Sistem Informasi STMIK AKBA ${ }^{1,2}$, Teknik Komputer STMIK AKBA ${ }^{3}$ \\ Email : astuty15@mhs.akba.ac.id¹, ratnawati@akba.ac.id², firstwanita@akba.ac.id ${ }^{3}$
}

\begin{abstract}
ABSTRAK
Dewasa ini semakin bermunculan berbagai macam penyakit gigi yang menyerang berbagai batasan usia mulai dari anak - anak sampai dewasa. Kehadiran dokter gigi tersebut sangat membantu dalam perawatan gigi dan mulut untuk mencegah kerusakan gigi atau perbaikan gigi yang sudah terlanjur rusak. Penelitian ini bertujuan untuk merancang aplikasi berbasis android untuk membantu dokter maupun pasien mengingat jadwal pengontrolan perawatan gigi dengan menggunakan fitur notifikasi. Aplikasi ini juga berfungsi dapat membantu pasien dan dokter mengakses history perawatan gigi, menampilkan informasi biaya, menyediakan fasilitas chat dan informasi dokter/pasien yang bersangkutan. Hasil dari penelitian ini yaitu aplikasi reminder jadwal pengontrolan perawatan gigi berbasis android. Aplikasi ini diimplementasikan dengan menggunakan bahasa pemrograman JavaScript, sistem operasi android dan firestore sebagai database. Metode pengumpulan data yang digunakan pada penelitian untuk aplikasi ini yaitu: Observasi, buku referensi android, jurnal, paper, dan yang dapat menunjang pemecahan permasalahan yang didapatkan dalam penelitian. Metode analisis meliputi metode analisis data, metode analisis sistem yang digunakan adalah Unified Modelling Languange (UML), dan metode pengujian yang digunakan yaitu black box testing sebagai testing pada software. Hasil rancangan aplikasi ini memudahkan dokter dan pasien untuk melihat history pemeriksaan gigi, mengingatkan jadwal pengontrolan perawatan gigi pada dokter dan pasien serta mendapatkan informasi biaya perawatan gigi pada klinik Goa Ria.
\end{abstract}

Kata Kunci: Android, Firebase, Jadwal Perawatan, Reminder.

\section{ABSTRCT}

Today there are increasingly various types of dental diseases that attack various age limits ranging from children to adults. The presence of the dentist is very helpful in dental and oral care to prevent tooth decay or repair teeth that have already been damaged. This study aims to design an android-based application to help doctors and patients remember the dental control schedule using the notification feature. This application also functions to help patients and doctors access the history of dental care, display information on costs, provide chat facilities and information about the doctor / patient in question. The results of this study are reminder application schedules for android-based dental care control. This application is implemented using the JavaScript programming language, Android operating system and Firestore as a database. Data collection methods used in research for this application are: Observations, android reference books, journals, papers, and those who can support solving problems obtained in research. The analytical method includes the method of data analysis, the system analysis method used is the Unified Modeling Language (UML), and the test method 
used is black box testing as software testing. The results of this application design make it easier for doctors and patients to see the history of dental examinations, remind dental control schedules for doctors and patients and get information on dental care costs at the Goa Ria clinic.

Keywords : Android, Firebase, Maintenance Schedule, Reminder.

\section{PENDAHULUAN}

\subsection{Latar Belakang}

Dewasa ini semakin bermunculan berbagai macam penyakit gigi yang menyerang berbagai batasan usia mulai dari anak - anak sampai dewasa. Karena kebutuhan tersebut maka mulai bermunculan klinik - klinik gigi yang menawarkan berbagai metode pemeliharaan dan perbaikan gigi oleh dokter spesialis gigi. Kehadiran dokter gigi tersebut sangat membantu dalam perawatan gigi dan mulut untuk mencegah kerusakan gigi atau perbaikan gigi yang sudah terlanjur rusak.

Perawatan gigi pada umumnya meliputi tindakan check-up (pemeriksaan rutin), scaling dan pembersihan, tambalan, ekstraksi gigi, pemasangan gigi palsu, perawatan ortodontik dan kawat gigi. Semua orang, termasuk anak-anak, sebaiknya mengunjungi dokter gigi minimal setiap enam bulan sekali, mengingat gigi permanen tumbuh hanya sekali seumur hidup, tidak ada lagi gigi setelah gigi permanen tanggal/rusak. Pemeriksaan gigi di klinik atau rumah sakit dapat membantu untuk mengetahui tingkat kesehatan gigi seseorang.

Di klinik Goa Ria saat selesai pemeriksaan, pasien hanya mengetahui jenis hasil pemeriksaan, pasien hanya mengetahui jenis hasil pemeriksaan yang dilakukan secara lisan dari hasil diagnosa dokter. Melihat akan pentingnya suatu teknologi yang dapat memudahkan pasien maupun dokter untuk mengingat waktu pengontrolan gigi di klinik tersebut. Hal ini juga sangat membantu dikarenakan kesibukan pasien yang terkadang dapat melewatkan waktu pengontrolan perawatan, selain itu masyarakat sekarang terbiasa menggunakan gadget dikehidupan sehari - hari terutama gadget berbasis android.

\section{LANDASAN TEORI}

\subsection{Penelitian Sebelumnya}

(a) Rancang Bangun Aplikasi Pengingat Kegiatan Akademik Berbasis Mobile oleh Findra Kartika Sari Dewi dkk pada tahun 2016.

(b) Aplikasi Pengingat Jadwal Kontrol Rutin ke Dokter Berbasis Mobile oleh Juni Nurma Sari pada tahun 2013.

(c) Rancang Bangun Aplikasi Mobile Untuk Notifikasi Jadwal Kuliah Berbasis Android (Studi Kasus : STMIK PROVINSI SEMARANG) oleh Taufik Ramadhan, Victor G Utomo pada tahun 2014.

\subsection{Reminder}

Reminder adalah sebuah pesan yang menolong seseorang untuk mengingat sesuatu. Reminder dapat lebih bermanfaat ketika informasi kontekstual digunakan untuk menyajikan informasi pada waktu dan tempat yang tepat. Reminder dapat 
digunakan sebagai manajemen waktu yang berfungsi untuk memberi alarm peringatan berupa pemberitahuan berbasis lokasi, waktu maupun catatan yang berupa kontekstual (Appsrox:2013).

Reminder biasanya berkaitan erat dengan alarm dan janji. Alarm pada umumnya untuk memberi peringatan kepada pengguna bahwa ada suatu kegiatan pada waktu yang telah ditentukan sebelum alarm itu berbunyi. Biasanya sebelum mengatur pengingat menggunakan reminder, dirancang dulu sebuah jadwal.

Perbedaan antara reminder dengan alarm terletak pada memo. Reminder bisa mencantumkan memo atau catatan sekaligus pengingat. Sedangkan untuk alarm hanya digunakan sebagai pengingat waktu. Reminder biasanya digunakan sebagai pencatat janji, jadwal keseharian, dan tugas-tugas sekolah. Untuk alarm pada umumnya digunakan sebagai alat bantu untuk membangunkan seseorang jika ingin melakukan kegiatan pada waktu yang telah ditentukan. Seiring berkembangnya jaman reminder bisa ditemui pada aplikasi diberbagai macam tipe handphone, begitu juga dengan alarm.

\subsection{Notifikasi}

Notifikasi dalam KKBI yaitu pemberitahuan atau kabar. Notifikasi /pemberitahuan di android merupakan sebuah pesan singkat yang terdapat diatas menubar android yang berfungsi menginformasikan jika ada event tertentu masuk atau keluar. Biasanya notifikasi ini dipakai pada aplikasi messaging, gaming, music, dan sebagainya. Untuk menampilkan notifikasi di android, kita dapat menggunakan beberapa komponen seperti kompononen Notification,
Notification Compat Builder dan Notification Manager.

\subsection{Android}

Menurut Yudhanto dan Wijayanto (2018:1) Android adalah sistem operasi berbabasis Linux yang dirancang untuk perangkat bergerak layar sentuh seperti telepon pintar dan komputer tablet. Awalnya, Google Inc. membeli Android Inc., pendatang baru yang membuat peranti lunak untuk ponsel. Kamudian untuk mengembangkan android, dibentuklah Open Handset Alliance, konsorsium dari 34 perusahaan peranti keras, peranti lunak, dan telekomunikasi, termasuk Google, HTC, Intel, Motorola, Qualcomm, T-Mobile, dan Nvidia.

Subset perangkat lunak untuk perangkat mobile yang meliputi sistem operasi, middleware, dan aplikasi inti yang dirilis oleh Google. Sedangkan Android SDK menyediakan Tools dan Application Programming Inferface (API) yang diperlukan untuk mengembangkan pada platform Android dengan menggunakan bahasa pemrograman Java.

\subsection{Android Studio Android}

Android Studio adalah sebuah IDE untuk Android Development yang diperkenalkan google pada acara Google I/O 2013. Android Studio merupakan pengembangkan dari Eclipse IDE, dan dibuat berdasarkan IDE Java populer, yaitu IntelliJ IDEA. Android Studio merupakan IDE resmi untuk pengembangan aplikasi android.

Sebagai pengembangan dari Eclipse, Android Studio mempunyai banyak fiturfitur baru dibandingkan dengan Eclipse 
IDE. Berbeda dengan Eclipse yang menggunakan Ant, android studio menggunakan Gradle sebagai build environment. Fitur-fitur lainnya adalah sebagai berikut :

1. Menggunakan Gradle-based build system yang fleksibel.

2. Bisa mem-build multiple APK

3. Template support untuk Google Services dan berbagai macam tipe perangkat

4. Layout editor yang lebih bagus.Built-in support untuk Google Cloud Platform, sehingga mudah untuk integrasi dengan Google Cloud Messaging dan App Engine

5. Import library langsung dari Maven repository

\subsection{Firebase}

Firebase memiliki produk utama, yaitu menyediakan database realtime dan backend sebagai layanan (Backend as a Service). Layanan ini menyediakan pengembang aplikasi API yang memungkinkan aplikasi data yang akan disinkronisasi di klien dan disimpan di cloud Firebase ini. Firebase menyediakan library untuk berbagai client platform yang memungkinkan integrasi dengan Android, iOS, JavaScript, Java, Objective-C dan Node aplikasi Js dan dapat juga disebut sebagai layanan DbaaS (Database as a Service) dengan konsep realtime. Firebase digunakan untuk mempermudah dalam penambahan fiturfitur yang akan dibangun oleh developer.

Sejarahnya, Firebase ini didirikan oleh dua sejoli bernama Andrew Lee dan James Tamplin pada tahun 2011 dan diluncurkan di tahun 2012. Produk utama dari Firebase adalah suatu database yang menyediakan API untuk memungkinkan pengembang (developer) menyimpan dan mensikronisasi data melalui multiple client. Perusahaan ini diakuisisi oleh Google pada Oktober 2014.

Firebase Authentication menyediakan layanan backend, SDK yang mudah digunakan, dan library UI yang siap pakai untuk mengautentikasi pengguna ke aplikasi. Firebase Authentication mendukung autentikasi menggunakan sandi, nomor telepon, penyedia identitas gabungan yang populer, seperti Google, Facebook, dan Twitter, dan lain-lain.

Database cloud NoSQL yang fleksibel dan skalabel guna menyimpan dan menyinkronkan data untuk pengembangan di sisi klien dan di sisi server. Cloud Firestore adalah database yang fleksibel dan skalabel untuk pengembangan seluler, web, dan server di firebase dan Google Cloud Platform. Seperti Firebase Realtime Database, Cloud Firestore membuat data tetap terhubung di aplikasi klien melalui listener realtime dan menawarkan dukungan secara offline untuk seluler dan web.

Firebase Hosting adalah layanan hosting konten web yang berkelas produksi untuk developer. Hanya dengan satu perintah, maka dapat menerapkan aplikasi web serta menyajikan konten statis dan dinamis ke CDN (jaringan penayangan konten) global dengan cepat.

Dengan Cloud Functions for Firebase, maka dapat menjalankan kode backend secara otomatis sebagai respons terhadap peristiwa yang dipicu oleh fitur Firebase dan permintaan HTTPS. Kode disimpan dicloud Google dan dijalankan dilingkungan yang terkelola sehingga 
tidak perlu mengelola atau menyesuaikan skala server sendiri.

Firebase Cloud Messaging (FCM) adalah solusi pengiriman pesan lintas platform yang memungkinkan dapat mengirimkan pesan dengan tepercaya tanpa biaya. Dengan FCM, dapat memberi tahu aplikasi klien bahwa email baru atau data lainnya tersedia untuk disinkronkan. FCM dapat mengirim pesan notifikasi untuk mendorong interaksi kembali dan retensi pengguna. Untuk kasus penggunaan seperti instant messaging, pesan dapat mentransfer payload hingga 4 KB ke aplikasi klien.

\section{METODE PENELITIAN}

\subsection{Metodologi Penelitian}

Metode pengumpulan data yang digunakan pada penelitian untuk aplikasi ini yaitu: Observasi keadaan Klinik Goa Ria terkhusus klinik gigi dan Pengumpulan data yang bersumber dari dokter spesialis gigi, buku referensi android, jurnal, paper, dan yang dapat menunjang pemecahan permasalahan yang didapatkan dalam penelitian.

\subsection{Metode Analisis}

Metode analisis merupakan suatu bentuk penganalisaan di dalam menguraikan informasi ke dalam komponen dengan maksud mengidentifikasi, mengevaluasi setiap permasalahan yang timbul. Metode analisis meliputi :

1. Analisis Data

Metode yang digunakan pada analisis data yaitu metode kualitatif berupa penganalisaan suatu data dan informasi yang bersifat teoritis.
2. Analisis Sistem

Metode analisis sistem yang digunakan adalah Unified Modelling Languange (UML) yaitu sebuah standar untuk merancang dan mendokumentasikan sistem piranti lunak terkhusus pada sistem yang berorientasi objek.

3. Analisis Pengujian

Metode pengujian yang digunakan yaitu black box testing sebagai testing pada software. Pengujian black box adalah pengujian yang didasarkan pada pengecekan terhadap detail perancangan, menggunakan struktur kontrol dari desain program secara procedural untuk membagi pengujian ke dalam beberapa kasus pengujian.

\subsection{Use case Diagram}

Use case menjelaskan apa yang akan dilakukan oleh sistem yang akan dibangun dan siapa yang berinteraksi dengan sistem tersebut.

\section{a) Use case Diagram Admin}

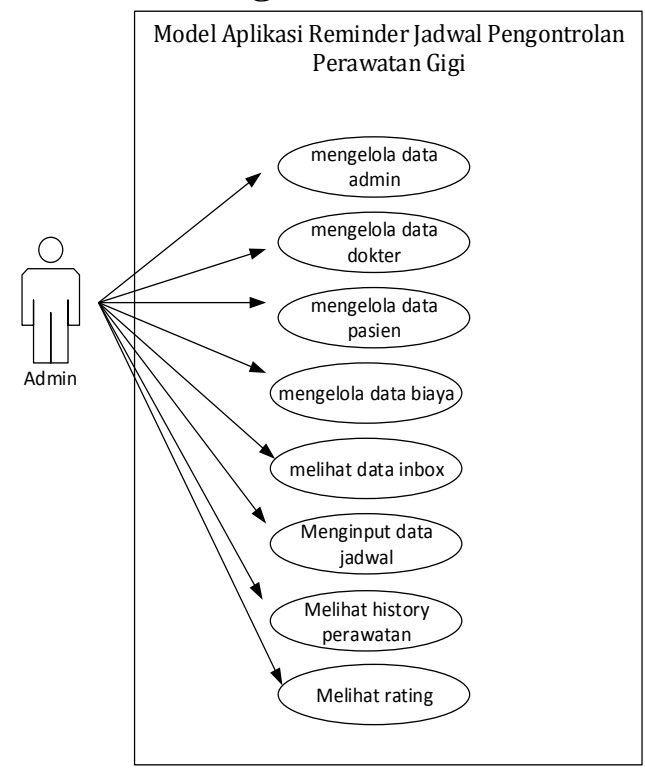

Gambar 1. Use Case Diagram Admin 
b) Use case Diagram Dokter

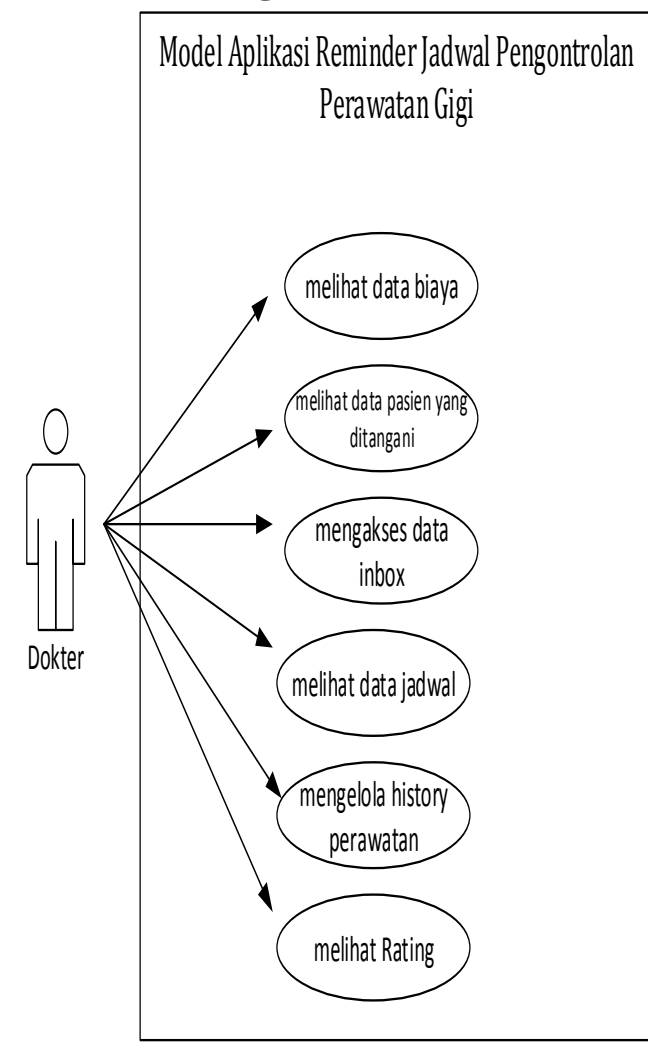

Gambar 2. Use Case Diagram Dokter

\section{c) Use Case Diagram Pasien}

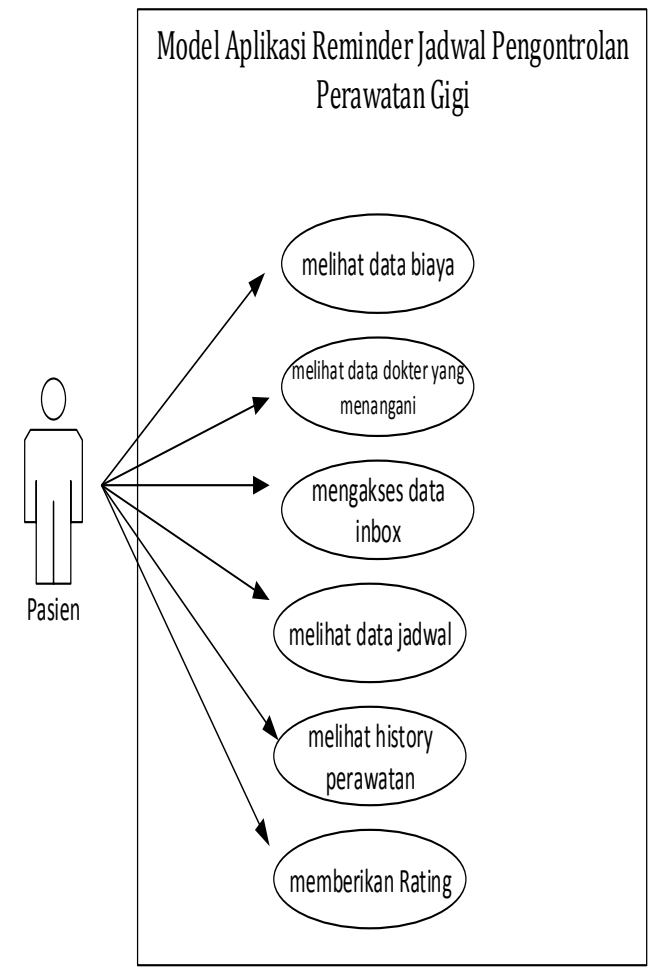

Gambar 3. Use Case Diagram Pasien

\subsection{Diagram Activity}

Activity Diagram merupakan diagram yang memodelkan alur kerja suatu proses bisnis dari suatu aktivitas ke aktivitas lain atau dari aktivitas ke status.Activity Diagram juga bermanfaat untuk menggambarkan interaksi antara beberapa use case.

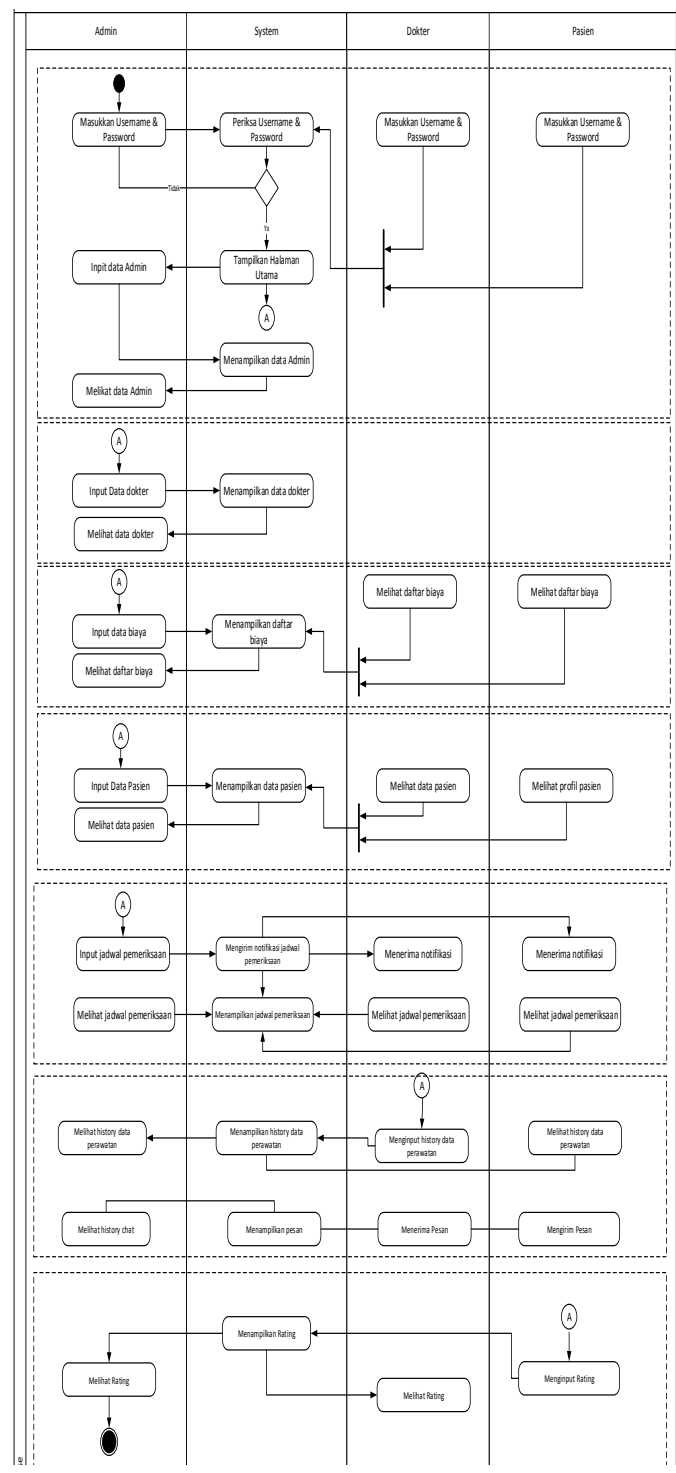

Gambar 4. Activity Diagram

\subsection{HASIL DAN PEMBAHASAN}

\subsection{Hasil Implementasi}

Berdasarkan langkah-langkah yang dilakukan pada tahap analisa dan perancangan sistem maka diperoleh 
hasil berupa aplikasi web dan aplikasi android.

a. Aplikasi pada WEB yang akan digunakan oleh admin.

1. Interface Login Admin

Untuk menjalankan aplikasi ini, admin harus masuk menggunakan email dan password yang telah terdaftar.

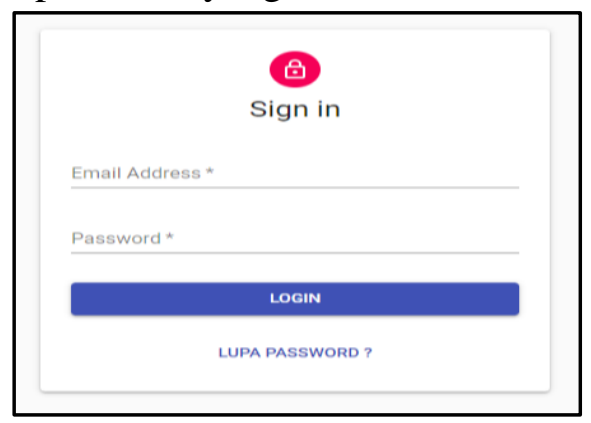

Gambar 5. Interface Login Admin

2. Halaman Data Admin

Pada halaman data admin, terdapat tombol Add untuk menambahkan data admin, tombol edit untuk mengedit data, tombol hapus untuk menghapus data admin dan pencarian untuk mencari data.

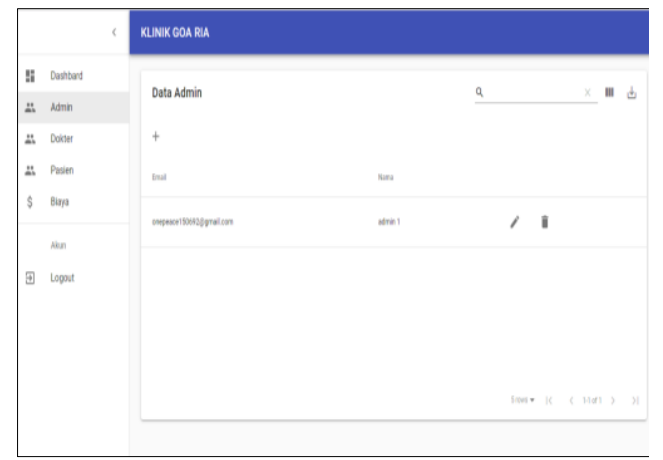

Gambar 6. Halaman Data Admin

\section{Halaman Data Dokter}

Pada halaman data dokter, terdapat tombol Add untuk menambahkan data dokter, tombol edit untuk mengedit data, tombol hapus untuk menghapus data, tombol jadwal untuk melihat history pemeriksaan pasien oleh dokter yang bersangkutan, terdapat tombol chat untuk melihat history chat pasien dan dokter yang bersangkutan, terdapat tombol rating untuk melihat jumlah rating dokter dan pencarian untuk mencari data.

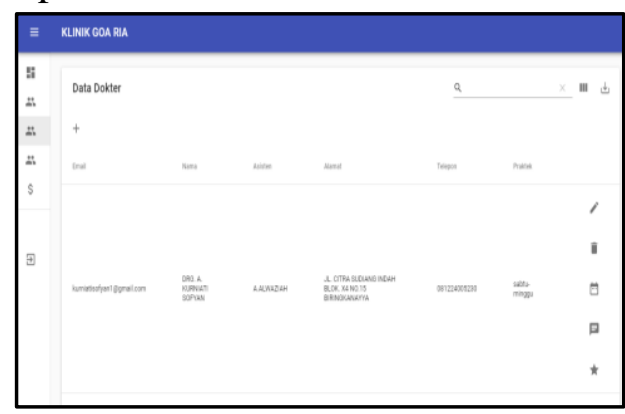

Gambar 7. Halaman Data Dokter

4. Halaman Data Pasien

Pada halaman data pasien, terdapat tombol Add untuk menambahkan data pasien, tombol edit untuk mengedit data, tombol hapus untuk menghapus data, tombol jadwal untuk melihat history pemeriksaan pasien oleh dokter yang bersangkutan, terdapat tombol chat untuk melihat history chat pasien dan dokter yang bersangkutan dan pencarian untuk mencari data.

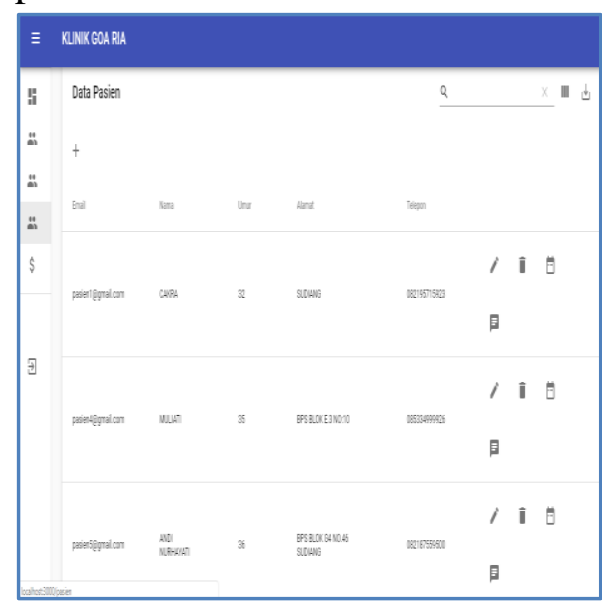

Gambar 8. Halaman Data Pasien 
b. Aplikasi pada smartphone Android yang akan digunakan oleh dokter dan pasien.

1. Halaman Login Dokter dan Pasien Untuk menjalankan aplikasi ini, dokter dan pasien harus memasukkan email dan password yang telah terdaftar.

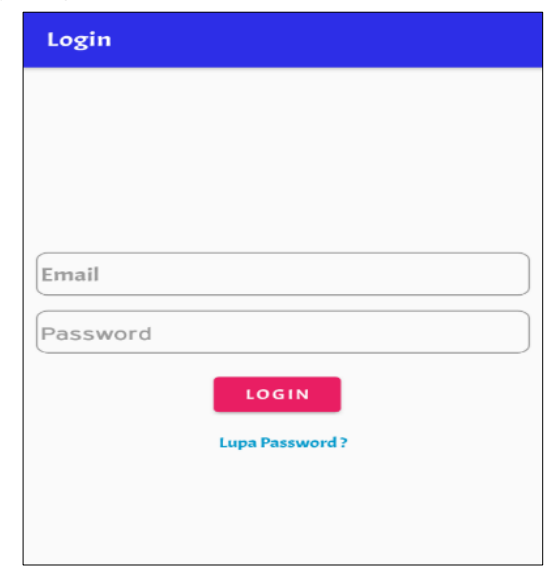

Gambar 9. Halaman Login Dokter dan Pasien

2. Halaman Jadwal \& History Pemerikasaan Level Dokter

Pada halaman jadwal \& history level dokter, terdapat tombol edit untuk menambahkan keterangan pemeriksaan gigi pasien.

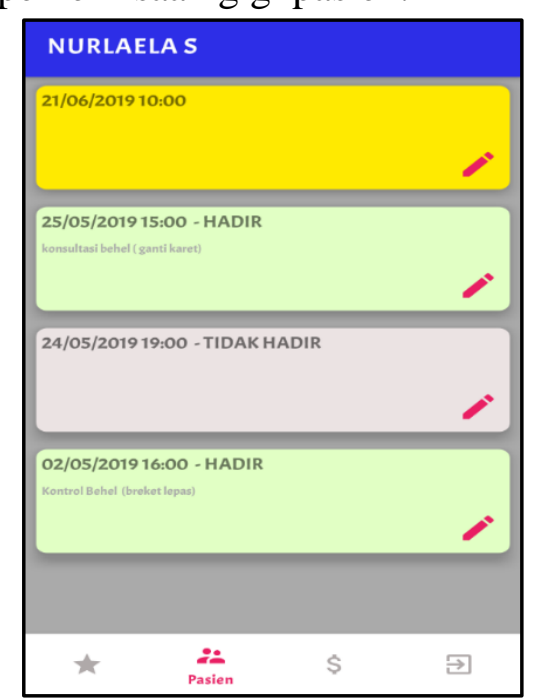

Gambar 10. Halaman Jadwal dan Hsitory Level Dokter
3. Halaman Jadwal \& History Pemeriksaan Level Pasien

Tampilan jadwal \& history pada level pasien, hanya dapat melihat jadwal yang akan datang dan history pemeriksaan yang ada.

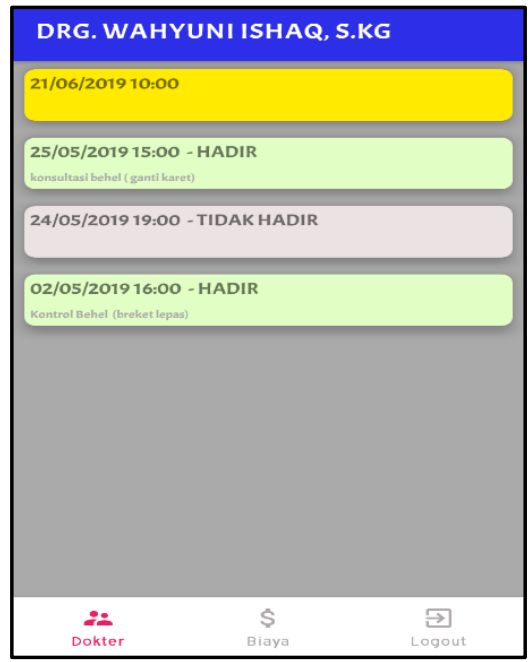

Gambar 11. Halaman Jadwal \& History Pemeriksaan Level Pasien

4. Halaman Chat Antara Dokter \& Pasien

Pada halaman chat antara dokter dan pasien, ada nama dokter/pasien yang ingin di chat, terdapat tombol kirim untuk mengirim pesan, dan dilengkapi waktu pengiriman pesan tersebut.

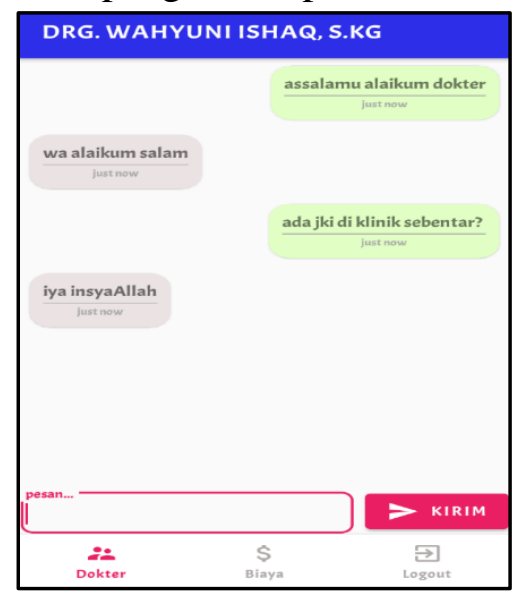

Gambar 12. Halaman chat antara dokter \& pasien 
5. Halaman Biaya Dokter dan Pasien Pada halaman biaya ini terdapat informasi harga dan jenis pemeriksaan.

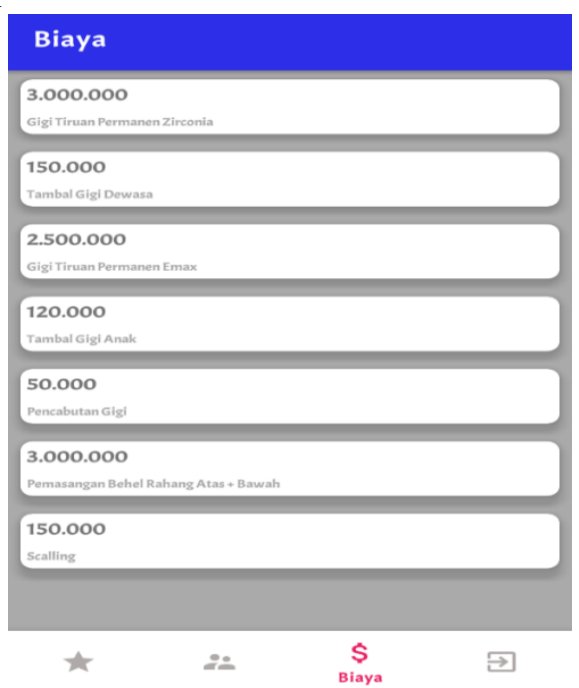

Gambar 13. Halaman Biaya Dokter dan Pasien

\section{Halaman Notifikasi}

Merupakan tampilan notifikasi yang terkirim ke dokter dan pasien. Notifikasi akan tampil sehari sebelum jadwal yang telah diatur oleh admin melalui dashboard. Informasi yang ditampilkan pada notifikasi ini yaitu tanggal pemeriksaan.

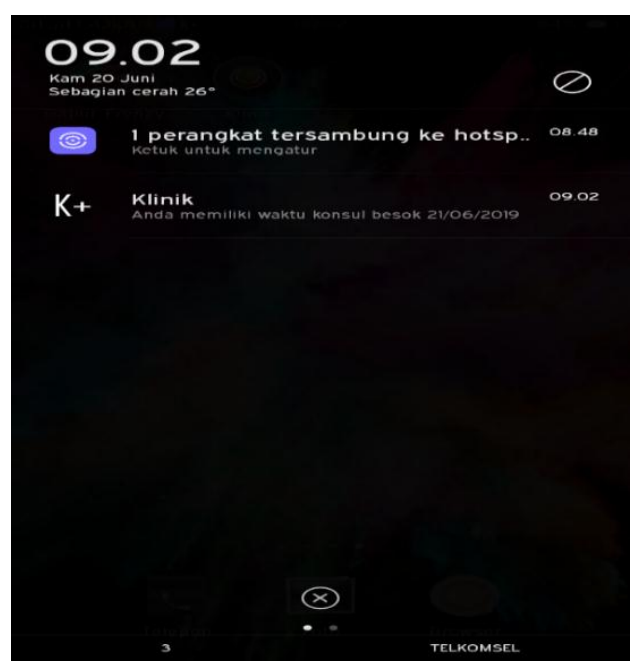

Gambar 14. Halaman Notifikasi

\subsection{Pengujian Sistem}

a. . Pengujian Mandiri

Pengujian mandiri dilakukan sebelum aplikasi ini diuji coba kepada pihak pengguna. Pengujian mandiri dilakukan dengan mengecek satu persatu menu yang ada. Pengujian ini dilakukan dengan metode blackbox. Pengujian blackbox berfokus pada sisi fungsionalitas, khususnya pada input dan output pada aplikasi apakah telah sesuai dengan yang diharapkan atau belum.

\section{b. Pengujian Kuesioner}

Pengujian kuesioner merupakan pengujian yang dilakukan secara objektif dimana aplikasi diuji secara langsung ke lapangan, yaitu dengan membuat kuesioner yang ditujukan kepada 10 pasien untuk menguji tampilan dan proses aplikasi reminder pengontrolan perawatan gigi.

Berdasarkan hasil pengujian sistem, keluaran dan aplikasi yang dirancang telah sesuai dengan yang diharapkan, sehingga dapat disimpulkan bahwa perancangan aplikasi ini berhasil.

\section{SIMPULAN DAN SARAN}

a. Kesimpulan

Dari hasil perancangan dan implementasi aplikasi reminder jadwal pengontrolan perawatan gigi di Klinik Goa Ria dapat ditarik kesimpulan yaitu aplikasi ini dirancang menggunakan firebase, Fitur-fitur firebase yang digunakan pada aplikasi ini yaitu firebase Authentication sebagai penyimpanan data pengguna, firebase firestore sebagai database, firebase 
cloud mesangging untuk mengirimkan notifikasi dan firebase function sebagai respons terhadap peristiwa yang dipicu oleh fitur firebase dan permintaan HTTPS.

Pengimplementasian aplikasi ini akan memudahkan dokter dan pasien untuk melihat history pemeriksaan gigi, mengingatkan jadwal pengontrolan perawatan gigi pada dokter dan pasien serta mendapatkan informasi biaya perawatan gigi pada klinik Goa Ria.

b. Saran

Kesempurnaan dari suatu sistem selalu bersifat relatif berdasarkan pada cara pandang dan konsep dari setiap pemikiran yang berbeda serta memiliki alur yang bervariasi. Saran bagi peneliti atau pengembangan sistem selanjutnya adalah:

1. Sistem ini dapat dikembangkan pada jenis perawatan lainnya.

2. Menambahkan pilihan feedback pada pasien untuk mengetahui kritik dan saran dalam menggunakan aplikasi.

\section{DAFTAR PUSTAKA}

Google Firebase. 2014. Firebase Helps mobile and web app teams succeed. Diambil dari https://firebase.google.com.

Juni Nurma sari. 2013. Aplikasi Pengingat Jadwal Kontrol Rutin Ke Dokter Berbasis Mobile. Pekanbaru : Politeknik Caltex Riau.

Taufik Ramadhan, Victor G Utomo. 2014. Rancang Bangun Aplikasi Mobile untuk Notifikasi Jadwal Kuliah berbasis Android. Semarang : STIMIK Provisi Semarang.

Wardhani, 2012. Analisis, Perancangan, dan Implementasi Aplikasi ContextAware Mobile Reminder. Yogyakarta.

Yudhanto, Yudha dan Ardhi Wijayanto. 2017. Mudah Membuat dan Berbisnis Aplikasi Android dengan Android Studio. Jakarta: PT. Alex Media Komputindo. 